ARMY OF SHADOWS 
The publisher gratefully acknowledges the generous contribution to this book provided by the Literature in Translation Endowment Fund of the University of California Press Foundation, which is supported by a major gift from Joan Palevsky. 


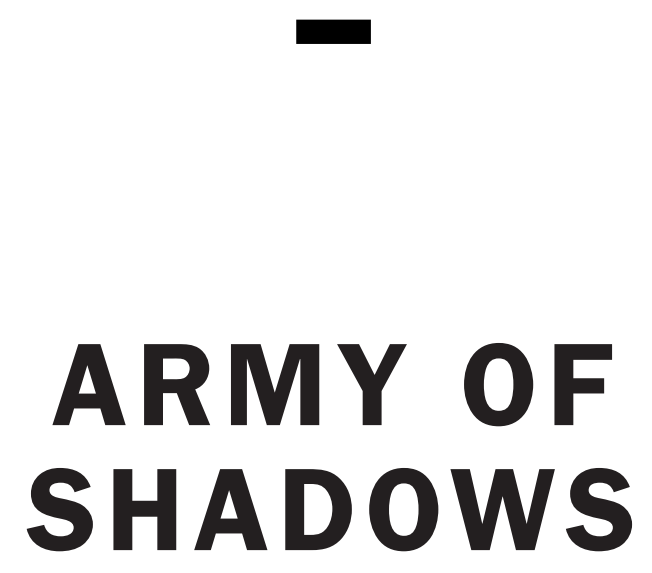

PALESTINIAN COLLABORATION

WITH ZIONISM, 1917-1948

\section{Hillel Cohen}

Translated by Haim Watzman

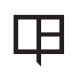

UNIVERSITY OF CALIFORNIA PRESS BERKELEY LOS ANGELES LONDON 
University of California Press, one of the most distinguished university presses in the United States, enriches lives around the world by advancing scholarship in the humanities, social sciences, and natural sciences. Its activities are supported by the UC Press Foundation and by philanthropic contributions from individuals and institutions. For more information, visit www.ucpress.edu.

University of California Press

Berkeley and Los Angeles, California

University of California Press, Ltd.

London, England

(C) 2008 by The Regents of the University of California

Library of Congress Cataloging-in-Publication Data

Cohen, Hillel.

[Tseva ha-tselalim. English]

Army of shadows : Palestinian collaboration with Zionism, I9I7-I948 / Hillel Cohen ; translated by Haim Watzman.

p. $\mathrm{cm}$

Includes bibliographical references and index. ISBN: 978-0-520-2522 I-9 (cloth : alk. paper)

I. Jewish-Arab relations-History-I9I7-I 948 .

2. Collaborationists. 3. Palestinian Arabs-Politics and government - 2oth century. 4. Zionism-

History - 2oth century. 5. Jews-Palestine-Politics and government-2oth century. I. Title.

DSII9.7.C6325I3 2008

$956.94^{\prime} \mathrm{O} 4-\mathrm{dc2} 2$

20070 II 57 I

Manufactured in the United States of America
$\begin{array}{lllllllll}\text { I } 5 & \text { I4 } & \text { I3 } & \text { I2 } & \text { II } & \text { IO } & \text { O9 } & 08 & 07\end{array}$

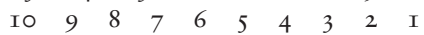

This book is printed on Natures Book, which contains $50 \%$ postconsumer waste and meets the minimum requirements of ANSI/NISO Z39.48-I992 (R I997) (Permanence of Paper). 